\title{
Top-Emission Organic Light Emitting Diode Fabrication Using High Dissipation Graphite Substrate
}

\author{
Yu-Sheng Tsai, ${ }^{1}$ Lin-Ann Hong, ${ }^{1}$ Jian-Ji Huang, ${ }^{2}$ Kuan-Hung Yeh, ${ }^{1}$ and Fuh-Shyang Juang ${ }^{1}$ \\ ${ }^{1}$ Master of Electro-Optical and Materials Science, National Formosa University, Yunlin 632, Taiwan \\ ${ }^{2}$ Department of Multimedia and Game Science, Chung Chou University of Science and Technology, Changhua 51003, Taiwan \\ Correspondence should be addressed to Lin-Ann Hong; jackie52046@yahoo.com.tw
}

Received 14 March 2014; Revised 14 May 2014; Accepted 22 May 2014; Published 2 July 2014

Academic Editor: K. R. Justin Thomas

Copyright (c) $2014 \mathrm{Yu}$-Sheng Tsai et al. This is an open access article distributed under the Creative Commons Attribution License, which permits unrestricted use, distribution, and reproduction in any medium, provided the original work is properly cited.

\begin{abstract}
This study uses a synthetic graphite fiber as the heat dissipation substrate for top-emission organic light emitting diode (TEOLED) to reduce the impact from joule heat. UV glue (YCD91) was spin coated onto the substrate as the insulation layer. The TEOLED structure is (glass; copper; graphite) substrate/YCD91 glue/Al/Au/EHI608/TAPC/ $\mathrm{Alq}_{3} / \mathrm{LiF} / \mathrm{Al} / \mathrm{Ag}$. The proposed graphite fiber substrate presents better luminous performance compared with glass and copper substrate devices with luminance of $3055 \mathrm{~cd} / \mathrm{m}^{2}$ and current efficiency of $6.11 \mathrm{~cd} / \mathrm{A}$ at $50 \mathrm{~mA} / \mathrm{cm}^{2}$. When lighting period of different substrates TEOLED, the substrate case back temperature was observed using different lighting periods. A glass substrate element operating from 5 to $25 \mathrm{~seconds}$ at $3000 \mathrm{~cd} / \mathrm{m}^{2}$ luminance produced a temperature rate of $1.207^{\circ} \mathrm{C} / \mathrm{sec}$. Under $4000 \mathrm{~cd} / \mathrm{m}^{2}$ luminance the copper and graphite substrate temperature rates were $0.125^{\circ} \mathrm{C} / \mathrm{sec}$ and $0.088^{\circ} \mathrm{C} / \mathrm{sec}$. Graphite component lifetime was determined to be 1.875 times higher than the glass components and 1.125 times higher than that of copper.
\end{abstract}

\section{Introduction}

Pope used anthracene monocrystals as luminescent materials in 1963 [1]. However, the operating voltage was higher with lower energy transformation efficiency and no application value [2]. Afterwards, Tang and VanSlyke, Kodak, USA, used vacuum evaporate plating to produce a multilayered OLED using small molecular organic $\mathrm{Alq}_{3}$ as the luminescent and charge transfer material. This innovation greatly improved OLED component characteristics to less than $10 \mathrm{~V}$ operating voltage with a quantum efficiency and device structure close to $1 \%$. Using non-mono-vacuum evaporate plating or close to amorphous organic semiconducting thin film technology created a device structure with heterogeneous multilayer organic film contact that greatly improved OLED device performance. This became the operating standard for current OLEDs [3, 4]. In 1990 the Cambridge research team successfully developed a yellow-green lumination LED [5] using PPV luminescent material. Because these macromolecular polymer materials possess characteristics similar to semiconductors and have a simple manufacturing process, they attracted great interest as a potential OLED polymer.
The substrate selection process used for TEOLED should consider the surface eveness, resistance to bumping, light weight, and thin, waterproof, and anticorrosive properties. For example, a plastic substrate possesses light, thin, short, and small advantages with resistance to fracture and reelability. However, most of these materials are not resistant to high temperature and are easily degraded by water and oxygen, further reducing the component service life [6]. Someone also attempted to produce OLEDs, a paper base, but there is still a long way to go before this product is ready for commercialization [7]. The introduction of metal foil as the substrate seems to solve the plastic substrate shortcomings with better energy dissipation that could strengthen the component operating time. However, the required surface polishing is something that requires great attention [8]. In 2001, Paulo N. M. Dos Anjos and others used $\mathrm{ITO} / \mathrm{NPB} / \mathrm{Alq}_{3} / \mathrm{Mg}: \mathrm{Ag}$ as the experimental structure and applied a buffer layer, $\mathrm{CuPc}$, onto the ITO electrode. From the experimental result, we can see that the structure temperature is $70^{\circ} \mathrm{C}$ without applying a buffer layer, reducing the temperature to $22^{\circ} \mathrm{C}$ after applying the buffer layer [9] 


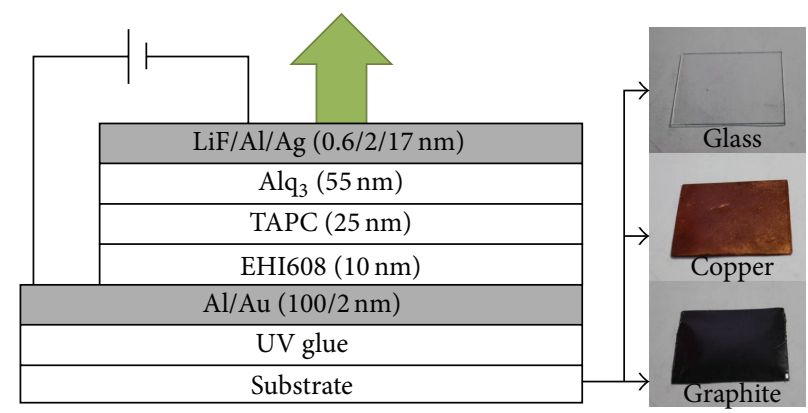

FIgURE 1: Component structure of TEOLED.

TABLE 1: Surface roughness characteristics of different substrates.

(a)

\begin{tabular}{lcccc}
\hline Number & Substrates & $\begin{array}{c}\text { UV glue } \\
\text { (YCD91) }\end{array}$ & $\begin{array}{c}\text { W/o UV glue } \\
(\text { Rms: nm) }\end{array}$ & $\begin{array}{c}\text { With UV glue } \\
(\text { Rms: nm) }\end{array}$ \\
\hline $\mathrm{a}$ & Glass & $18 \mu \mathrm{m}$ & 4.37 & 2.97 \\
$\mathrm{~b}$ & Copper & $19 \mu \mathrm{m}$ & 3.27 & 2.85 \\
$\mathrm{c}$ & Graphite & $21 \mu \mathrm{m}$ & 15.07 & 0.68 \\
\hline
\end{tabular}

${ }^{*}$ Material composition (YCD91).

(b)

\begin{tabular}{lccc}
\hline Oligomer-TM621 & Monomer-2PEA & TMPTA-20EA & Photo initiator 184 \\
\hline 40 & 30 & 30 & $1.5 \%$ \\
\hline
\end{tabular}

K. Sudheendra Rao et al. raised the device with structure ITO/m-MTDATA/NPB/Alq ${ }_{3}: \mathrm{C} 545 \mathrm{~T} / \mathrm{Alq}_{3} / \mathrm{LiF} / \mathrm{Al}$. As a standard procedure $\mathrm{Alq}_{3}$ is doped with C545T for optimized efficiency (12 cd/A) [10].

\section{Experimental}

The substrate is spin coated onto glass, copper, and graphite substrates at $1200 \mathrm{rpm}$ for 15 seconds and at $2400 \mathrm{rpm}$ for 20 seconds of UV glue (YCD91) (from Material and Chemical Research Laboratories, Industrial Technology Research Institute). YCD91 was exposed under UV light for 75 seconds to cure. Correct curing produces appropriate substrate material viscosity, which produces uniform spin coating. The treated substrates were placed into a metal thermal system and vacuumized to $6.65 \times 10^{-4} \mathrm{~Pa}$. $\mathrm{Al}$ and $\mathrm{Au}$ metals were then vacuum evaporized according to the sequence. The substrates were then placed in an organic evaporator and vacuumed to $6.65 \times 10^{-4} \mathrm{~Pa}$. Hole injection layer (HIL) material EHI608, hole transport layer (HTL) material TAPC, and emitting layer material (EML) or electron transport layer (ETL) $\mathrm{Alq}_{3}$ were then vacuum evaporated according to the sequence. The LiF, $\mathrm{Al}$, and Ag cathode metals were then vacuum evaporated in sequence. The finished TEOLED components were tested for luminous characteristics and temperture at the substrate back using multifunctional ammeter KEITHLEY 2400, spectrophotometer PR650, and IR camera NEC TH7716.

\section{Results and Discussion}

3.1. Characteristics Comparison of Different TEOLED Device Substrates. The TEOLED device structure is $\mathrm{Al}(100 \mathrm{~nm}) / \mathrm{Au}$ $(2 \mathrm{~nm}) / \mathrm{EHI} 608(10 \mathrm{~nm}) / \mathrm{TAPC} \quad(25 \mathrm{~nm}) / \mathrm{Alq}_{3} \quad(55 \mathrm{~nm}) / \mathrm{LiF}$ $(0.6 \mathrm{~nm}) / \mathrm{Al}(2 \mathrm{~nm}) / \mathrm{Ag}(17 \mathrm{~nm})$ as indicated in Figure 1 . The material thickness of each OLED layer is listed in Table 2. The UV glue (YCD91) material, including heat dissipation particles, was spin coated onto glass, copper, and graphite substrates and then left exposed in air for hardening. The substrate surface roughness was then analyzed using atomic force microscopy (AFM) as shown in Figure 2 and Table 1. The measurement results show that the Rms roughness of the glass, copper, and graphite substrates before spin coating was 4.37, 3.27, and $15.07 \mathrm{~nm}$ and 2.97, 2.85, and $0.68 \mathrm{~nm}$ after spin coating and drying. Because the graphite substrate is obtained from carbon fiber the surface roughness is quite high. After UV glue spin coating the material roughness was significantly reduced to Rms $0.68 \mathrm{~nm}$. Table 2 shows the roughness comparison of each spin coated UV plastic substrate material.

The TEOLED device with the graphite substrate exhibited that operating voltage is $14.6 \mathrm{~V}$, lower than that of the glass and copper substrates at $15 \mathrm{~V}$ and $15.5 \mathrm{~V}$ at $50 \mathrm{~mA} / \mathrm{cm}^{2}$. The luminance and current efficiency of the graphite substrate were $3054 \mathrm{~cd} / \mathrm{m}^{2}$ and $6.11 \mathrm{~cd} / \mathrm{A}$, respectively, compared with those of the cooper substrate $\left(2835 \mathrm{~cd} / \mathrm{m}^{2}\right.$ and $\left.5.67 \mathrm{~cd} / \mathrm{A}\right)$ and the glass substrate $\left(2730 \mathrm{~cd} / \mathrm{m}^{2}\right.$ and $\left.5.46 \mathrm{~cd} / \mathrm{A}\right)$. Comparing the 
TABLE 2: Parameter of each layer for TEOLED (unit: $\mathrm{nm}$ ).

\begin{tabular}{|c|c|c|c|c|c|c|c|c|c|}
\hline Number & Substrate (with UV glue) & $\mathrm{Al}$ & $\mathrm{Au}$ & $\begin{array}{c}\text { HIL } \\
\text { EHI608 }\end{array}$ & $\begin{array}{c}\text { HTL } \\
\text { TAPC }\end{array}$ & $\begin{array}{c}\text { EML/ETL } \\
\mathrm{Alq}_{3}\end{array}$ & $\begin{array}{l}\text { EIL } \\
\mathrm{LiF}\end{array}$ & $\mathrm{Al}$ & $\mathrm{Ag}$ \\
\hline I & Glass & & & & & & & & \\
\hline II & Copper & 100 & 2 & 10 & 25 & 55 & 0.6 & 2 & 17 \\
\hline III & Graphite & & & & & & & & \\
\hline
\end{tabular}
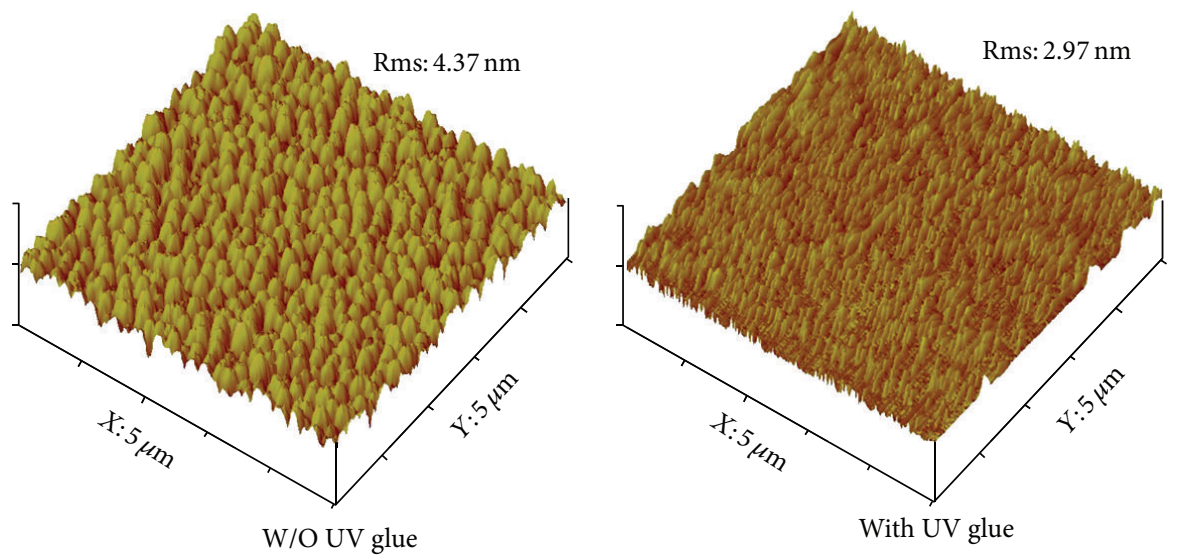

(a) Glass

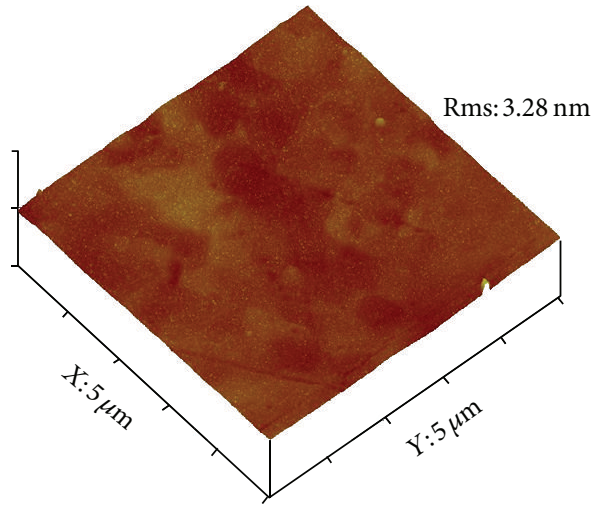

W/O UV glue

(b) Copper

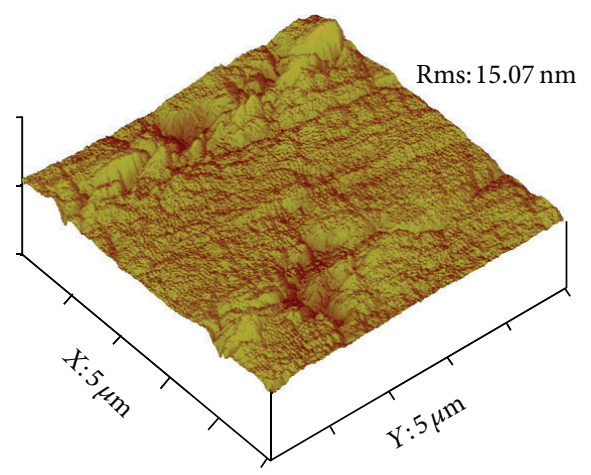

W/O UV glue

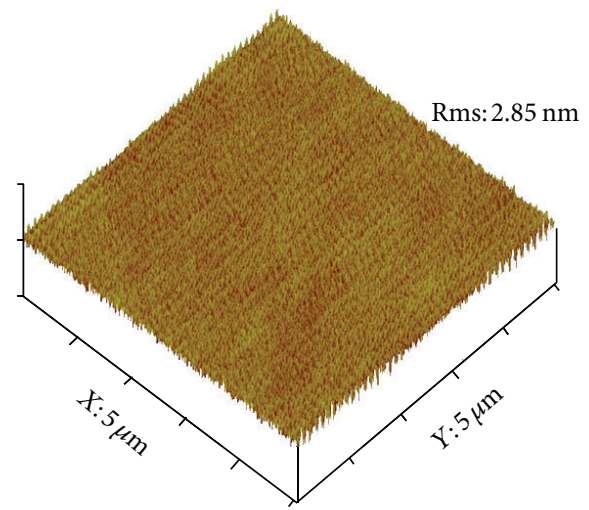

With UV glue

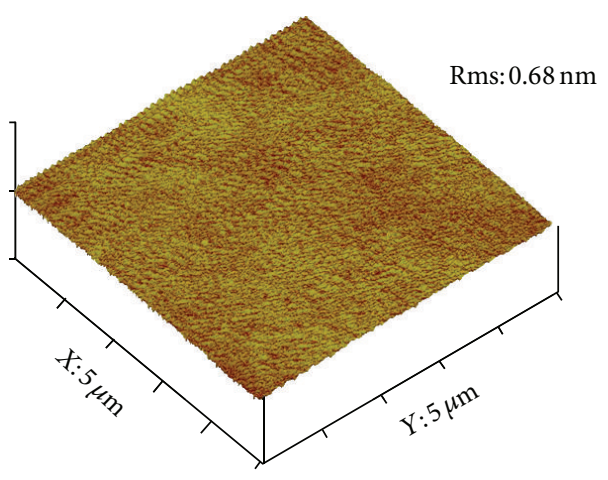

With UV glue

(c) Graphite

Figure 2: UV glue spin coated onto three substrates by AFM. 


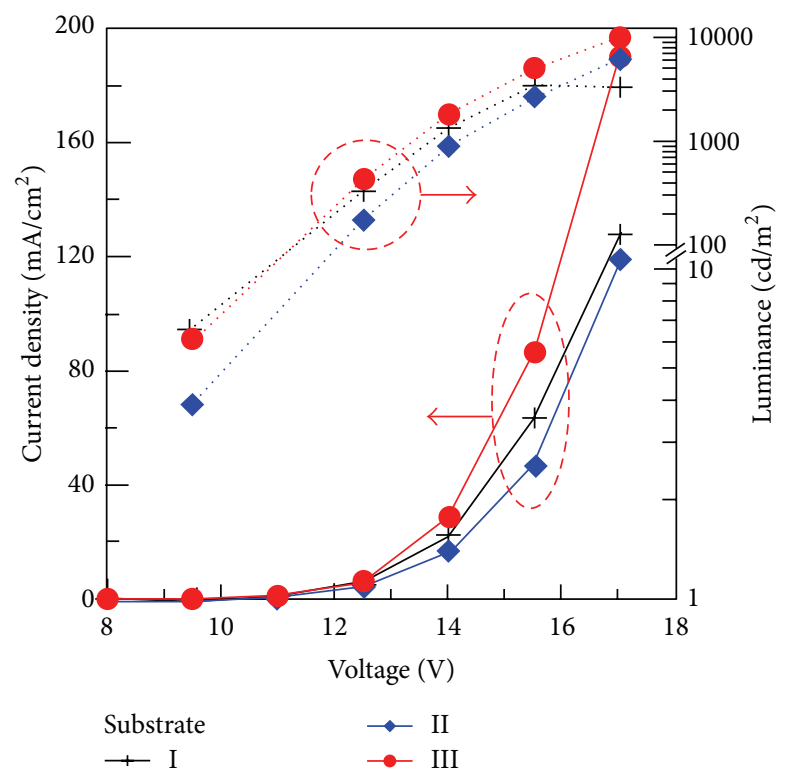

(a)

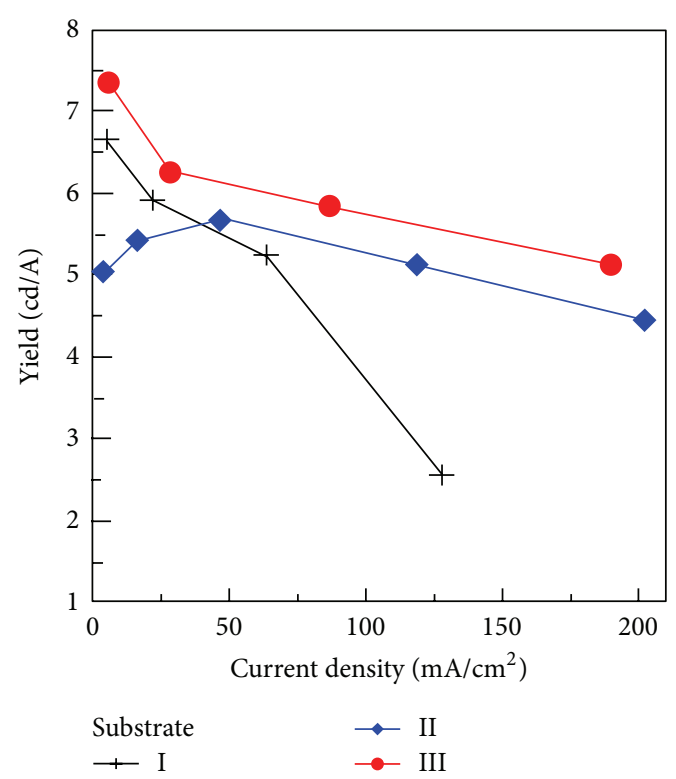

(b)

FIGURE 3: (a) Current density-voltage-luminance. (b) Current efficiency-current density of TEOLED.

TABLE 3: Thermal conductivity value for glass, copper, and graphite fiber.

\begin{tabular}{lc}
\hline Substrate materials & Thermal conductivity value $(\mathrm{W} / \mathrm{m} * \mathrm{~K})$ \\
\hline Glass & 1.38 \\
Copper & 398 \\
Graphite fiber & $400 \sim 500$ \\
\hline
\end{tabular}

luminous characteristics of graphite, copper, and glass, we can see that materials with higher substrate thermal conductivity coefficient achieve better luminous characteristics compared with the glass substrate. The heat dissipating substrate could also elevate the device stability, allowing operation at higher voltage.

The thermal conductivity coefficients for the graphite and copper substrates are much better than that of glass, as indicated in Table 3. From Figure 2 these three substrates are relatively closer in device characteristics at low voltage. However, under high voltage the thermal conductivity of glass restrained the device from dissipating heat, leading to organic layer material crystallization, making the overall device luminous characteristics worse. The graphite and copper substrate devices could maintain higher luminance and current efficiency under higher operating voltage. The thermal conductivity of graphite fiber is better than that of copper. At a current density from 50 to $175 \mathrm{~mA} / \mathrm{cm}^{2}$, Device III current efficiency roll-off is $18.1 \%$ while that of Device II is $21.3 \%$, both better than Device I (roll-off is $51.3 \%$ at current density from 50 to $125 \mathrm{~mA} / \mathrm{cm} 2$ ) (see Figure 3).

Using material with high thermal conductivity coefficient as the TEOLED substrate could make TEOLED devices achieve better luminous characteristics. At the same time it could also dissipate the heat, removing the negative impact on device luminous characteristics at high voltage. The heat flow reference is defined in (1), within a setting time $(t)$; the heat $(Q)$ flows from the plane of a higher temperature $\left(T_{H}\right)$ to the plane of a lower temperature $\left(T_{C}\right)$ where $A$ is the area, $L$ the length, and $k$ the material thermal conductivity. However, (1) is specifically for the rate of heat flow for a single layer material. The OLED device is composed of two electrodes and multiple organic layers. Therefore the above equation should be replaced with (2) [11]. Consider

$$
\begin{gathered}
H\left(=\frac{Q}{t}\right)=k A \frac{T_{H}-T_{C}}{L}, \\
H=\frac{A\left(T_{H}-T_{C}\right)}{\sum_{i}\left(L_{i} / k_{i}\right)},
\end{gathered}
$$

$$
\begin{aligned}
& H_{\text {(glass;copper;graphite) }} \\
& =A\left(T_{H}-T_{C}\right) \\
& \times\left(\frac{10 \times 10^{-9} \mathrm{~m}}{k_{\mathrm{EHI} 608}}+\frac{25 \times 10^{-9} \mathrm{~m}}{k_{\mathrm{TAPC}}}+\frac{55 \times 10^{-9} \mathrm{~m}}{k_{\mathrm{Alq}_{3}}}\right. \\
& +\frac{2 \times 10^{-9} \mathrm{~m}}{k_{\mathrm{Au}}}+\frac{100 \times 10^{-9} \mathrm{~m}}{k_{\mathrm{Al}}} \\
& +\left(\left(18 \times 10^{-6} ; 19 \times 10^{-6} \text { copper } ;\right.\right. \\
& \left.\quad 21 \times 10^{-6} \text { graphite } \mathrm{m} \times\left(k_{\text {glue }}\right)^{-1}\right) \\
& \left.\left.+\frac{0.5 \times 10^{-3} \mathrm{~m}}{k_{\text {(glass;copper;graphite) }}}\right)\right)^{-1} .
\end{aligned}
$$



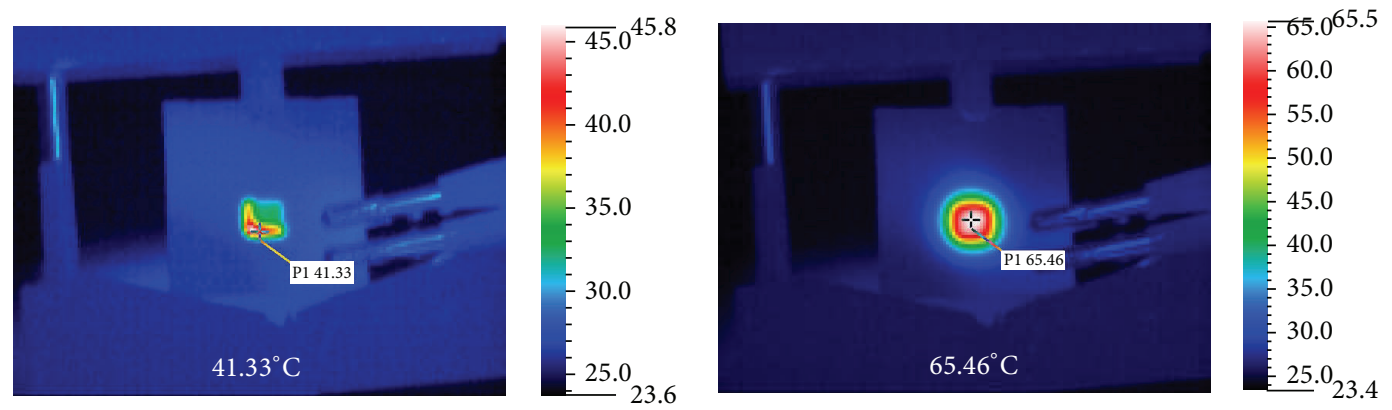

(a) Glass
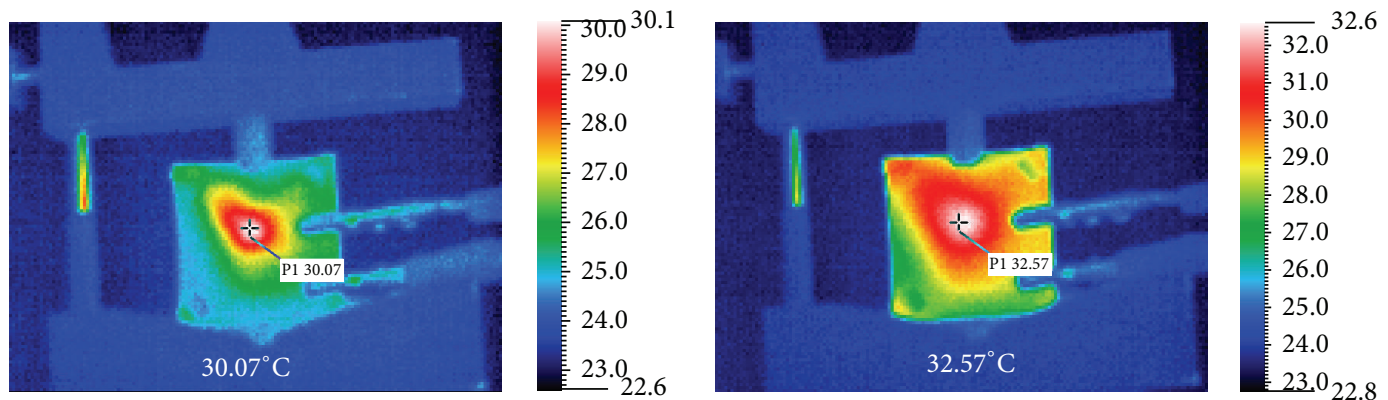

(b) Copper
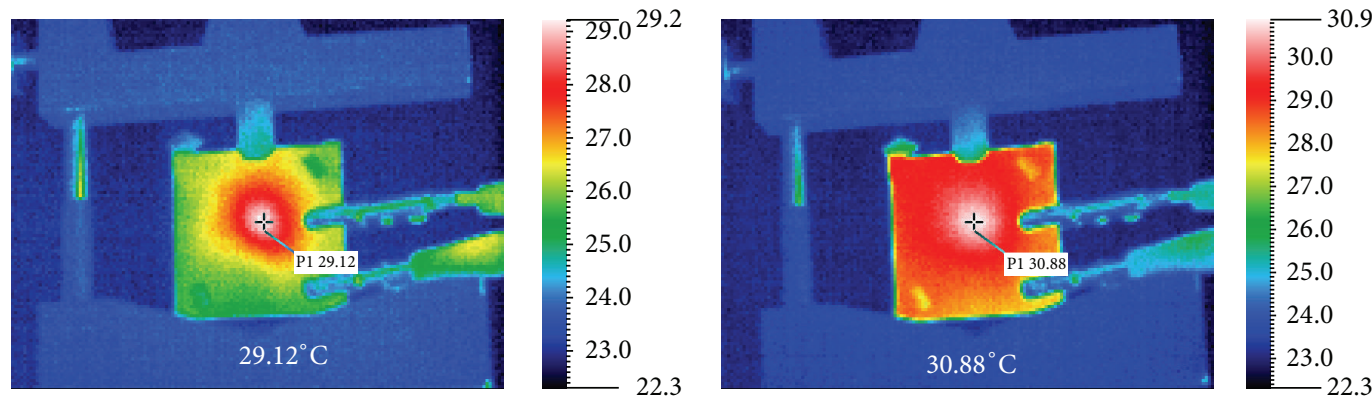

(c) Graphite

FIGURE 4: Temperature when (a) the glass (b) copper or (c) graphite substrate device is operated. Lift is operated for 5 seconds; right is operated for 25 seconds.

Comparing (3) for the current TEOLED structure, the key factors affecting the heat flow rate are the thermal conductivity $(k)$, substrate thickness $(L)$, and UV glue materials. Since the thermal conductivity of graphite is about $k_{\text {graphite }}$ $=400 \sim 500 \mathrm{~W} / \mathrm{m} \cdot \mathrm{K}$, copper is about $k_{\text {copper }}=397 \mathrm{~W} / \mathrm{m} \cdot \mathrm{K}$, glass is about $k_{\text {glass }}=1.38 \mathrm{~W} / \mathrm{m} \cdot \mathrm{K}$, and UV glue is about $k_{\mathrm{YCD} 91}=0.5 \mathrm{~W} / \mathrm{m} \cdot \mathrm{K}$, the rate of heat flow for TEOLED with a graphite substrate is better than that of both copper and glass substrates. Figure 4 shows the measured junction temperature and surface thermal distribution image results.

3.2. Heat Dissipation Test of TEOLED Devices. Substrate temperature tests were conducted using copper, graphite, and glass substrates on the emission area and substrate back after operating from 5 to 25 seconds. When the luminance was $3000 \mathrm{~cd} / \mathrm{m}^{2}$ (current density of $57 \mathrm{~mA} / \mathrm{cm}^{2}$ ) for the glass substrate device, the device highest temperature area was the emission area about $41.33^{\circ} \mathrm{C}$ as indicated in Figure 4(a). With 25 -second operation the temperature increased to $65.46^{\circ} \mathrm{C}$, concentrated in the emission area. When the copper substrate device was operated at $4000 \mathrm{~cd} / \mathrm{m}^{2}$ luminance (current density of $\left.75 \mathrm{~mA} / \mathrm{cm}^{2}\right)$, its back temperature was at $30.07^{\circ} \mathrm{C}$ as indicated in Figure 4(b). The temperature increased slightly to $32.57^{\circ} \mathrm{C}$ after lighting for 25 seconds. The temperature at the back of the substrate was $29.12^{\circ} \mathrm{C}$ when the graphite substrate component was operated at $4000 \mathrm{~cd} / /^{2}$ luminance (current density of $68 \mathrm{~mA} / \mathrm{cm}^{2}$ ) as indicated in Figure 4(c). The temperature increased slightly to $30.88^{\circ} \mathrm{C}$ after lighting for 25 seconds. When the device was emitted for a certain period the device surface was cooler than that of copper and glass. The above study result shows that the high thermal conductivity characteristics of the graphite fiber substrate could effectively dissipate the heat produced from the device during high voltage operation.

Three TOLEDs with different substrates were packaged in PET for component lifetime measurements. At $500 \mathrm{~cd} / \mathrm{m}^{2}$ of luminance, Figure 5 shows that the glass substrate had a lifetime of only 4 hours due to poor heat dissipation. 


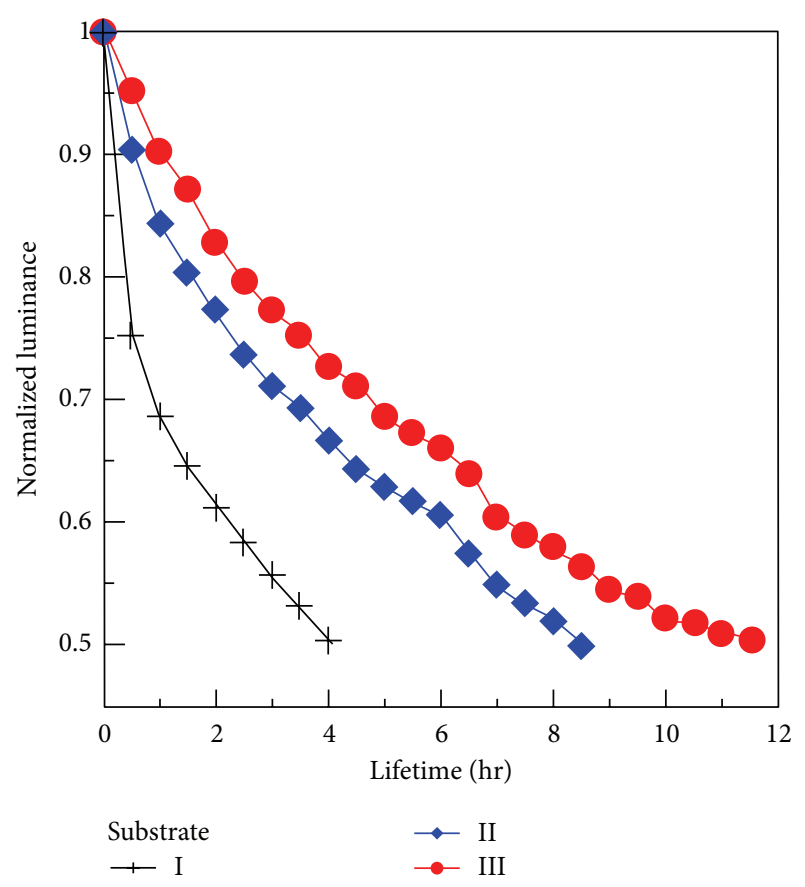

Figure 5: Component lifetime curves of the different substrates.

The graphite substrate component lifetime was 11.5 hours due to better cooling.

\section{Conclusions}

The TEOLED structure is (glass; copper; graphite) substrate/YCD91 glue/Al/Au/EHI608/TAPC/Alq $/ 2 / \mathrm{LiF} / \mathrm{Al} / \mathrm{Ag}$. From the experimental results the graphite fiber substrate produced better luminous performance compared with the glass and copper substrate devices at luminance of $3055 \mathrm{~cd} / \mathrm{m}^{2}$ and current efficiency of $6.11 \mathrm{~cd} / \mathrm{A}$ at $50 \mathrm{~mA} / \mathrm{cm}^{2}$. At a current density from 50 to $175 \mathrm{~mA} / \mathrm{cm}^{2}$, Device III current efficiency roll-off was $18.1 \%$. The substrate case back temperature was observed for different TEOLED substrates operated at several lighting periods. A glass substrate element operating from 5 to 25 seconds of luminance at 3000 $\mathrm{cd} / \mathrm{m}^{2}$ produced a temperature rate of $1.207^{\circ} \mathrm{C} / \mathrm{sec}$. Under luminance of $4000 \mathrm{~cd} / \mathrm{m}^{2}$ the copper and graphite substrate temperature rates were $0.125^{\circ} \mathrm{C} / \mathrm{sec}$ and $0.088^{\circ} \mathrm{C} / \mathrm{sec}$. Glass, copper, and graphite comparative operating lifetimes were 4 , 8.5 , and 11.5 hours, respectively.

\section{Conflict of Interests}

The authors declare that there is no conflict of interests regarding the publication of this paper.

\section{Acknowledgments}

This work is sponsored by the Ministry of Science and Technology of Taiwan, Projects NSC99-2221-E-235-005, NSC1012221-E-235-008, and NSC102-2221-E-150-066-MY2. Special thanks are due to Shu-Ling Yeh researcher team from Material and Chemical Research Laboratories, Industrial Technology Research Institute, for the UV glue (YCD91).

\section{References}

[1] M. Pope, H. P. Kallmann, and P. Magnante, "Electroluminescence in organic crystals," The Journal of Chemical Physics, vol. 38, no. 8, pp. 2042-2043, 1963.

[2] A. Kraft, A. C. Grimsdale, and A. B. Holmes, "Electroluminescent conjugated polymers-seeing polymers in a new light," Angewandte Chemie International Edition, vol. 37, no. 4, pp. 402-428, 1998.

[3] C. W. Tang and S. S. van Slyke, "Organic electroluminescent diodes," Applied Physics Letters, vol. 51, no. 12, pp. 913-915, 1987.

[4] C. W. Tang, S. A. van Slyke, and C. H. Chen, "Electroluminescence of doped organic thin films," Journal of Applied Physics, vol. 65, no. 9, pp. 3610-3616, 1989.

[5] J. J. Burroughes, D. D. C. Bradley, A. R. Brown et al., "Lightemitting diodes based on conjugated polymers," Nature, vol. 347, pp. 539-541, 1990.

[6] G. Gustafsson, Y. Cao, G. M. Treacy, F. Klavetter, N. Colaneri, and A. J. Heeger, "Flexible light-emitting diodes made from soluble conducting polymers," Nature, vol. 357, no. 6378, pp. 477-479, 1992.

[7] C. J. Lee, D. G. Moon, and J. I. Han, "Sports over a distance, portraits with a sense of their personal space, and telephones crossed with flotation tanks," in Proceedings of the 3rd Workshop on Social Intelligence Design (SID '04), p. 1005, Seattle, DC, USA, May 2004.

[8] C. C. Wu, S. D. Theiss, G. Gu et al., "Integration of organic LED's and amorphous Si TFT's onto flexible and lightweight metal foil substrates," IEEE Electron Device Letters, vol. 18, no. 12, pp. 609612, 1997.

[9] P. N. M. dos Anjos, H. Aziz, N.-X. Hu, and Z. D. Popovic, "Temperature dependence of electroluminescence degradation in organic light emitting devices without and with a copper phthalocyanine buffer layer," Organic Electronics, vol. 3, no. 1, pp. 9-13, 2002.

[10] K. S. Rao and Y. N. Mohapatra, "Disentangling degradation and auto-recovery of luminescence in Alq3 based organic light emitting diodes," Journal of Luminescence, vol. 145, pp. 793-796, 2014.

[11] Y. Tsai, S. Wang, C. Chen et al., "Using copper substrate to enhance the thermal conductivity of top-emission organic light-emitting diodes for improving the luminance efficiency and lifetime," Applied Physics Letters, vol. 95, no. 23, Article ID 233306, 2009. 

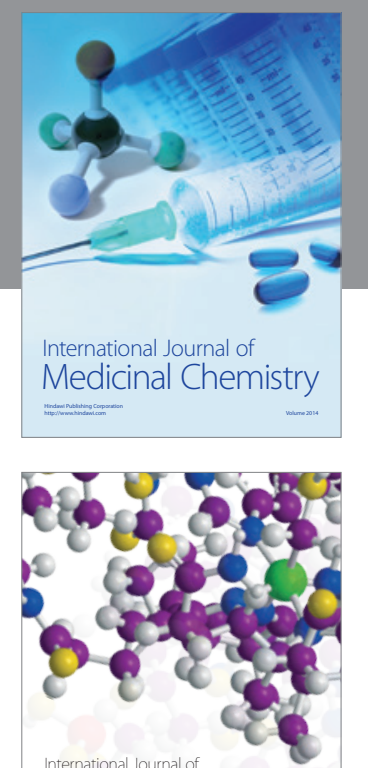

\section{Carbohydrate} Chemistry

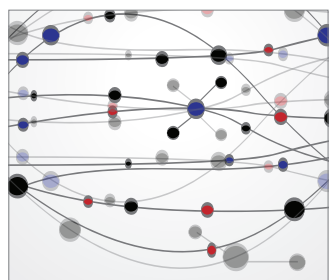

The Scientific World Journal
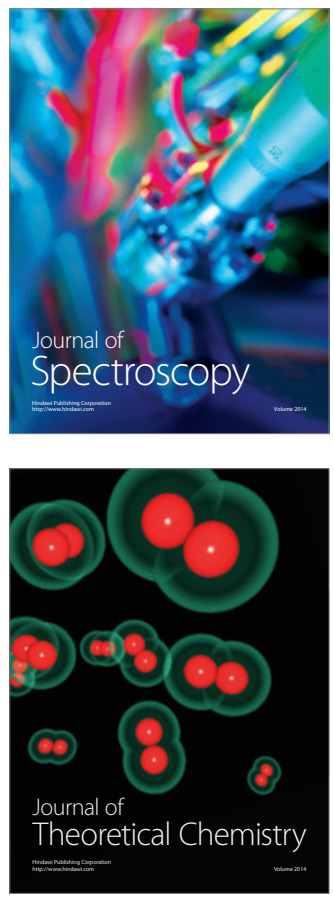
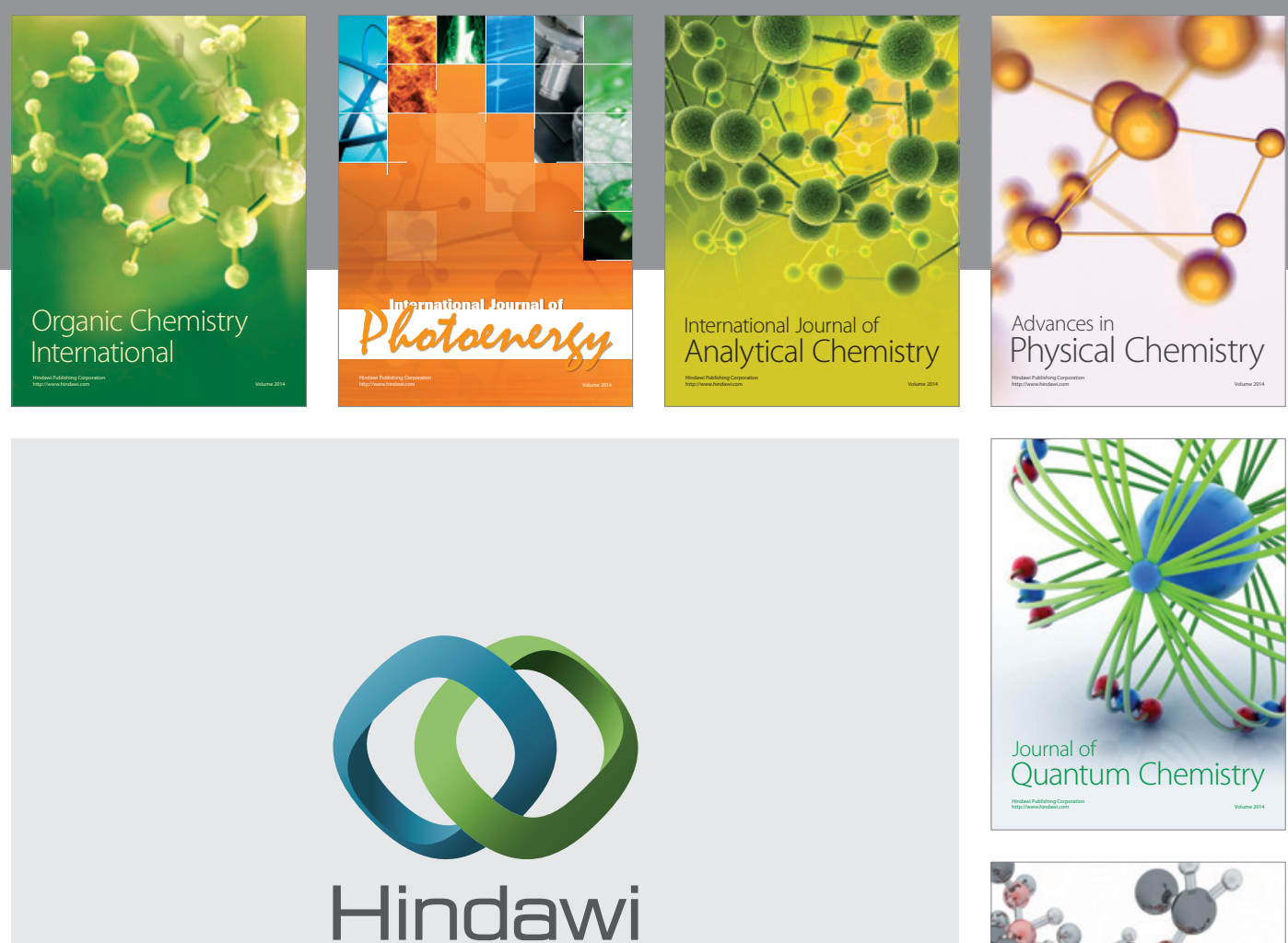

Submit your manuscripts at

http://www.hindawi.com

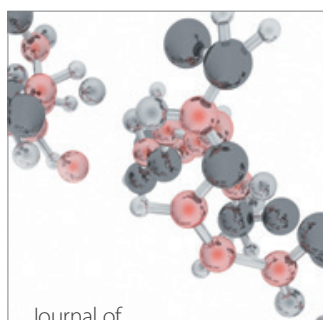

Analytical Methods

in Chemistry

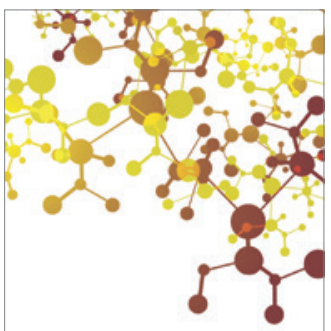

Journal of

Applied Chemistry

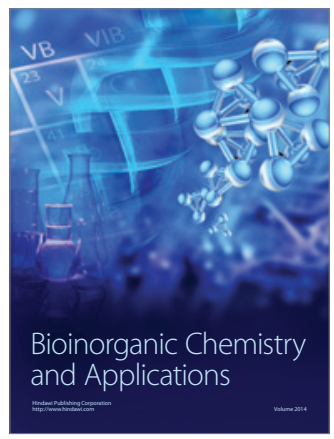

Inorganic Chemistry
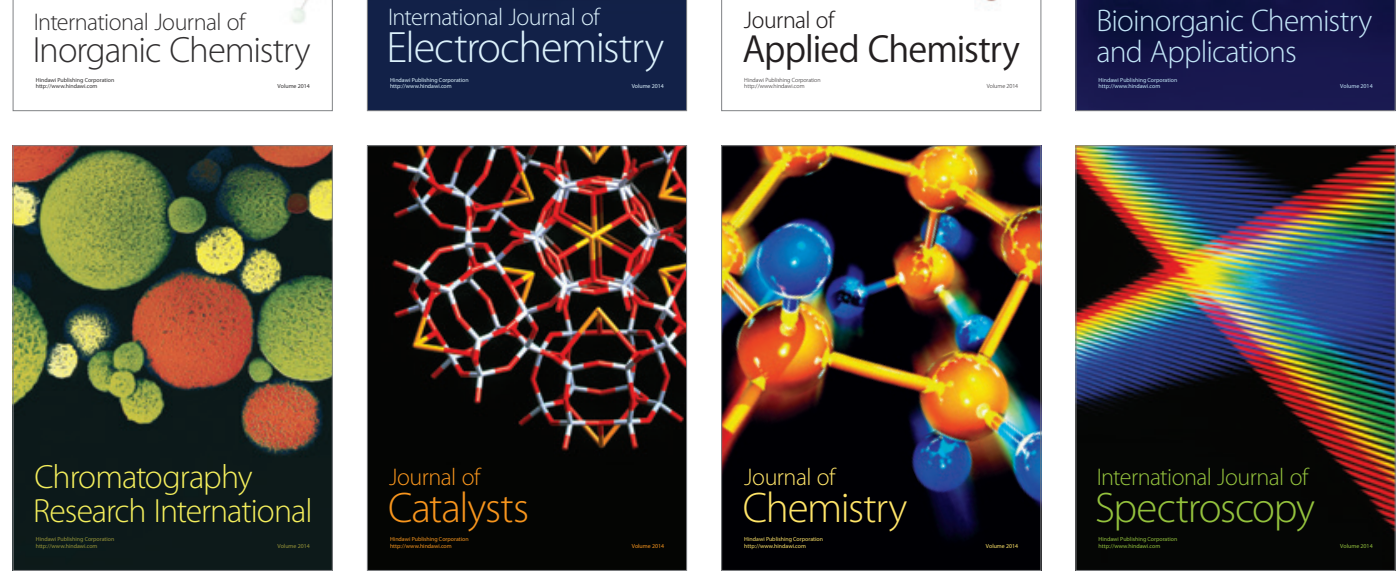